\title{
The Appointment in Samarra: A New Use for Some Old Jokes
}

\author{
Slavoj Žižek
}

Received: 28 June 2020 / Accepted: 3 August 2020

(C) Journal of Bioethical Inquiry Pty Ltd. 2020

\begin{abstract}
The coronavirus epidemic is not just a biological phenomenon which affects humans: it is also a moment of a profound global and ecological crisis that includes many human and nonhuman actors. To confront the crisis, a radical philosophical change is needed, which penetrates to natural, economic, and cultural processes. The amassing of dictatorial powers of state apparatuses evoked by the pandemic highlights their basic impotence and the fact that the system as we know it cannot continue in its existing liberal-permissive form. While the final outcome is uncertain what is most probable is that a new barbarian capitalism will prevail: many old and weak will be sacrificed and let to die, workers will have to accept much lower standards of living, digital control of our lives will remain a permanent feature, and class distinctions will become much more than now a matter of life and death.
\end{abstract}

Keywords COVID-19 C Coronavirus · Pandemic . Ethics · Capitalism · Ecological crisis · Assemblage · Climate change

In my past work, I used — at least a dozen times - the old joke about a man who believes himself to be a grain of seed and is taken to a mental institution where the doctors do their best to finally convince him that he is

\section{S. Žižek $(\bowtie)$}

University of Ljubljana, Ljubljana Slovenia

e-mail: slavoj.zizek@guest.arnes.si a human being. When he is cured - convinced that he is not a grain of seed but a man - and allowed to leave the hospital, he immediately comes back trembling with fear. There is a chicken outside the entrance door and he is afraid that it will eat him.

"Dear fellow," says his doctor, "you know very well that you are not a grain of seed but a man."

"Of course, I know that," replies the patient, "but does the chicken know it?"

My Croat friend Dejan Kršić recently sent me a corona version of this joke:

"Hello, my friend!"

"Oh, hello, professor! Why are you wearing a mask? Two weeks ago, you were explaining all around that masks don't protect against the virus?" "Yes, I know they don't work, but maybe the virus doesn't know it!"

This virus version of the joke is based, of course, on the crucial fact that a virus doesn't know anything (and also doesn't not know anything) because it doesn't dwell in the domain of knowledge at all. It is not an enemy trying to destroy us - it just self-reproduces with a blind automatism. Some leftists evoke another parallel: is capital also not a virus parasitizing on us humans, is it also not a blind mechanism bent on expanded selfreproduction in total indifference to our suffering? There is, however, a key difference at work here: capital is a virtual entity which doesn't exist in reality independently of us. It only exists insofar as we, humans, participate in the capitalist process. As such, capital is a spectral entity: if we stop acting as if we believe in it (or, say, if a 
state power nationalizes all productive forces and abolishes money), capital ceases to exist. The virus, however, is a part of reality which can be dealt with only through science.

This does not mean that there is no link between the different levels of viral entities: biological viruses, digital viruses, and capital. The coronavirus epidemic itself is clearly not just a biological phenomenon which affects humans: to understand its spread, one has to include human culture (especially food habits), the economy and global trade, the thick network of international relations, and ideological mechanisms of fear and panic. To properly grasp this link, a new approach is needed. The path is shown by Bruno Latour (2020) who is right to emphasize that the coronavirus crisis is a "dress rehearsal" for the forthcoming climate change which is

... the next crisis, the one in which the reorientation of living conditions is going to be posed as a challenge to all of us, as will all the details of daily existence that we will have to learn to sort out carefully. (II1)

The coronavirus epidemic as a moment of the global and lasting ecological crisis brutally imposes on us

... the sudden and painful realization that the classical definition of society-humans among themselves - makes no sense. The state of society depends at every moment on the associations between many actors, most of whom do not have human forms. This is true of microbes-as we have known since Pasteur-but also of the internet, the law, the organization of hospitals, the logistics of the state, as well as the climate. (II2)

There is, of course, as Latour is well aware, a key difference between the coronavirus epidemic and the ecological crisis:

... in the health crisis, it may be true that humans as a whole are "fighting" against viruses — even if they have no interest in us and go their way from throat to throat killing us without meaning to. The situation is tragically reversed in ecological change: this time, the pathogen whose terrible virulence has changed the living conditions of all the inhabitants of the planet is not the virus at all, it is humanity! (II8)
Although Latour immediately adds that "this does not apply to all humans, just those who make war on us without declaring war on us," the agency which "makes war on us without declaring war on us" is not just a group of people but the existing global socioeconomic system - in short, the existing global order in which we all (humanity as a whole) participate. We can see now in what resides the truly subversive potential of the notion of assemblage: it comes forth when we apply it to describe a constellation which also comprises humans but from an "inhuman" standpoint, so that humans appear in it as just one among the actants. Recall Jane Bennett's description of how actants interact at a polluted trash site: how not only humans but also the rotting trash, worms, insects, abandoned machines, chemical poisons, and so on each play their (never purely passive) role (Bennett 2010, 4-6). There is an authentic theoretical and ethico-political insight in such an approach. When the so-called new materialists like Bennett oppose the reduction of matter to a passive mixture of mechanical parts, they are, of course, not asserting the old-fashioned direct teleology but an aleatoric dynamics immanent to matter: emerging properties arise out of non-predictable encounters between multiple kinds of actants, the agency for any particular act is distributed across a variety of kinds of bodies. Agency thereby becomes a social phenomenon where the limits of sociality are expanded to include all material bodies participating in the relevant assemblage. An ecological public, for example, is a group of bodies, some human, most not, that are subjected to harm, defined as a diminished capacity for action. The ethical implication of such a stance is that we should recognize our entanglement within larger assemblages: we should become more sensitive to the demands of these publics and the reformulated sense of self-interest calls upon us to respond to their plight. Materiality, usually conceived as inert substance, should be rethought as a plethora of things that form assemblages of human and nonhuman actors (actants). Humans are but one force in a potentially unbounded network of forces.

Such an approach, which locates a phenomenon in its ever-changing assemblage, enables us to account for some unexpected cases of trans-functionalization (that is, where a phenomenon all of a sudden begins to function in a totally different way). Among the unexpected occurrences of solidarity, one should mention the gangs in Rio de Janeiro favelas, usually engaged in brutal struggles for the control of their territories, who 
concluded peace for the time of the epidemic and decided to collaborate in providing help to the old and weak. ${ }^{1}$ This sudden change was possible because street gangs were already in themselves an assemblage of different aspects: not just a form of crime but also a form of solidarity and resistance by groups of youth to institutional power.

Another example of trans-functionalization: spending trillions to help not only companies but also individuals (some of these measures come close to universal basic income). This is justified as an extreme measure to keep the economy running and to prevent extreme poverty and starvation, but there is effectively something much more radical going on. With such measures, money no longer functions in a classic capitalist way; it becomes a voucher to allocate available resources so that society can go on functioning, outside the constraints of the law of value.

Let's imagine another weird reversal along these lines. It was widely reported in our media how a collateral effect of the coronavirus epidemics was a much better quality of air above central China and now even above northern Italy - but what if weather patterns in these regions have come to depend upon polluted air, so that one of the effects of cleaner air may turn out to be a different and much more destructive pattern of weather in these regions (more drought or more flooding)?

To confront the forthcoming ecological crisis, a radical philosophical change is thus needed, much more radical than the usual platitude of emphasizing how we, humans, are part of nature, one of the natural species on Earth. What is needed is a recognition of how our productive processes (our metabolism with nature, as Marx put it) is part of the metabolism within nature itself. The challenge is to describe this complex interaction in its detailed texture. Coronavirus is not an exception or a disturbing intrusion; it is a particular version of the virus which was operative beneath the threshold of our perception for decades. Viruses and bacteria are all the time here, sometimes even with crucial positive function (our digestion works only through the bacteria in our stomach). It is not enough to introduce here the notion of different ontological strata (as bodies, we are organisms which have to host bacteria and viruses; as producers, we collectively change the nature around us; as political beings, we organize our social life and

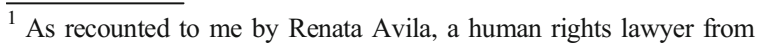
Guatemala.
}

engage in struggles in it; as spiritual beings, we find fulfilment in science, art, and religion; etc.). "Assemblage" means that one has to make a step further here towards a kind of flat ontology and deploy how these different levels can interact at the same ontological level: viruses as actants are mediated by our productive activities, by our cultural tastes, by our social commerce. This is why, for Latour, as articulated by Müller (2015, 31),

... politics should become material, a Dingpolitik revolving around things and issues of concern, rather than around values and beliefs. Stem cells, mobile phones, genetically modified organisms, pathogens, new infrastructure and new reproductive technologies bring concerned publics into being that creates diverse forms of knowledge about these matters and diverse forms of action beyond institutions, political interests or ideologies that delimit the traditional domain of politics. ${ }^{2}$

Again, is the coronavirus epidemic not such an assemblage of a (potentially) pathogenic viral mechanism, industrialized agriculture, fast global economic development, cultural habits, exploding international communication, and so on? The epidemic is a mixture in which natural, economic, and cultural processes are inextricably mixed. As an unabashed philosopher of subjectivity, I think I should nonetheless add two points here. First, as humans, we are one among the actants in a complex assemblage; however, it is only and precisely as subjects that we are able to adopt the "inhuman view" from which we can (partially, at least) grasp the assemblage of actants of which we are part.

Second, "values and beliefs" should not be simply ignored: they do play an important role and should be treated as a specific mode of assemblage. Religion is a complex texture of dogmas, institutions, social and individual practices, and intimate experiences where what is said and what remains unsaid is intertwined in often unexpected ways - perhaps, a full scientific proof that god exists would be the greatest surprise for the believer him/herself. A similar complexity (or, rather, a rift) helps us to understand the belatedness of our reaction

\footnotetext{
${ }^{2}$ It seems to me that the prevalent normative reading of Hegel à la Brandom ignores this intertwinement of normative stances and claims with a complex network of material and immaterial life processes.
} 
to the coronavirus spread-our knowledge was out of sync with our spontaneous beliefs.

Recall the second murder (of the detective Arbogast) from Hitchcock's Psycho: this murder is a surprise, even more than the notorious shower murder. The shower murder was a totally unexpected surprise, while herewe knew something shocking was going to happen, the whole scene is shot to indicate it - we are still surprised when it happens. Why? How can the greatest surprise occur precisely when what we were told would happen did happen? The obvious answer is because we didn't really believe it would happen. And did not something similar happen with the spread of coronavirus? Epidemiologists were warning us the virus would reach us; they gave precise predictions which are now proven accurate. Greta Thunberg was right when she claims that politicians should listen to science, but we were prone to trust our "hunches" more (Trump used this word) - and it is easy to understand why. What is now going on is something we considered impossible till now, the basic coordinates of our lifeworld are disappearing. Our first reaction to the virus was that it was just a nightmare from which we would soon awaken. Now we know this will not happen, we will have to learn to live in a viral world, a new lifeworld will have to be painfully reconstructed.

But there is another combination of speech and reality at work in the ongoing pandemic: there are material processes which can happen only if they are mediated through our knowledge. We are told a catastrophic X will happen to us, we try to avoid it, and through our very attempts to avoid it, it happens. Recall the old Arab story about the "appointment in Samarra" retold by W. Somerset Maugham: a servant on an errand in the busy market of Baghdad meets Death there. Terrified by her gaze, he runs home to his master and asks him to give him a horse, so that he can ride all day and reach Samarra, where Death will not find him, in the evening. The good master not only provides the servant with a horse but goes himself to the market, looks for Death and reproaches her for scaring his faithful servant. Death replies that she didn't want to scare the servant; she was just surprised to find him there in Bagdad when they have an appointment in Samarra that night. What if the message of this story is not that a man's demise is impossible to avoid, that trying to twist free of it will only tighten its grip, but rather its exact opposite, namely that if one accepts fate as inevitable, one can break its grasp? It was foretold to Oedipus's parents that their son would kill his father and marry his mother, and the very steps they took to avoid this fate (exposing him to death in a deep forest) made sure that the prophecy would be fulfilled-without this attempt to avoid fate, fate could not have realized itself. Is this not a clear parable of the fate of the U.S. intervention in Iraq? The United States saw the signs of the fundamentalist threat, intervened to prevent it, and thereby strengthened it. Would it not have been much more effective to accept the threat, ignore it, and thus break its grasp? So, back to our story, imagine that, upon encountering Death in the market, the servant had said: "What's your problem with me? If you have something to do with me, do it. Otherwise beat it!"

Perplexed even more, Death would have mumbled something like: "But we were supposed to meet in Samarra, I cannot kill you here!” and run away (probably to Samarra). Therein resides the wager of the socalled herd immunity coronavirus plan:

The stated aim has been to achieve "herd immunity" in order to manage the outbreak and prevent a catastrophic "second wave" next winter. A large proportion of the population-roughly speaking anyone up to the age of forty-is at lower risk of developing severe disease. So, the reasoning goes, that even though in a perfect world we'd not want anyone to take the risk of infection, generating immunity in younger people is a way of protecting the population as a whole (Hanage 2020).

The wager here is that if we act as if we don't know - that is, if we ignore the threat - the actual damage might be smaller than if we act knowingly. This is what conservative populists try to convince us: the Samarra of our appointment is our economic order and our entire way of life, so that if we hear the warning of epidemiologists and react to it by escaping our reality (through isolation and lockdown, etc.), we will bring forth a much greater catastrophe (poverty and suffering) than the small percentage of deaths from the virus.

However, as Alenka Zupančič (pers. comm.) has pointed out to me, "let's go back to work" is an exemplary case of what is false in Trump's care for the working class: he addresses ordinary poorly paid people for whom the pandemic is also an economic catastrophe, who cannot afford isolation, for whom economic collapse is an even greater threat than the virus. The catch is, of course, double here. First, Trump's economic politics (dismantling the welfare state) is to a large extent responsible for the fact that many poorly paid workers find themselves in such a dire situation that, for them, poverty is a greater threat than the virus. 
Second, those who will really "go to work" are those same workers - the poor-while the rich will persist in their comfortable isolation. We should always bear in mind that there are those who cannot self-isolate, not only all those who make our isolation possible (healthcare workers, food producers, and those who take care of its delivery, those who take care of electricity and water supply, etc.) but also refugees/migrants who simply have no place to withdraw to in self-isolation. How to explain a need to keep social distance to thousands confined to a refugee camp? Just recall the chaos in India when the government ordered a fourteen-day lockdown, with millions from the big cities trying to reach the countryside.

All these new divisions point to the fatal limitation of the left-liberal worry that the enhanced social control triggered by the virus threat will remain and constrain our freedom since individuals reduced to the panic of mere survival are ideal subjects of power. The danger is very real - the extreme case is that of Viktor Orban who passed a law which enables him to rule by decree for an indefinite period of time. However, this worry misses what is effectively going on today, which is almost the exact opposite: although those in power are trying to make us responsible for the outcome of the crisis (maintain the proper distance, follow our orders, each of you is now responsible), the reality is exactly the opposite one. The message of us, the subjects, to the state power is that we gladly follow your orders, but they are your orders, and there is no guarantee that our obeying them will fully work. The state power is in panic because they know not only that they don't control the situation, they also know that we, their subjects, know this - the impotence of power is revealed now.

We all know the classic scene from cartoons: the cat reaches a precipice, but it goes on walking, ignoring the fact that there is no ground under its feet; it starts to fall only when it looks down and notices the abyss. ${ }^{3}$ When it loses its authority, the regime is like a cat above the precipice: in order to fall, it only has to be reminded to look down. But the opposite also holds. When an authoritarian regime approaches its final crisis, its dissolution as a rule follows two steps. Before its actual collapse, a mysterious rupture takes place. All of a sudden people know that the game is over. They are simply no longer afraid. It is not only that the regime loses its

\footnotetext{
$\overline{3}$ There is probably no book of mine in which I do not refer to it at least once.
}

legitimacy, its exercise of power itself is perceived as an impotent panic reaction. In Shah of Shahs, a classic account of the Khomeini revolution, Ryszard Kapuscinski located the precise moment of this rupture: at a Tehran crossroad, a single demonstrator refused to budge when a policeman shouted at him to move, and the embarrassed policeman simply withdrew. In a couple of hours, all Tehran was talking about this incident, and although there were street fights going on for weeks, everyone somehow knew the game was over (Kapuscinski 1992). There are indications that something similar could be going on today: all the dictatorial powers the state apparatuses are amassing just makes all the more palpable their basic impotence.

We should resist here the temptation of celebrating this disintegration of our trust as an opening for the people to self-organize locally outside the state apparatuses: an efficient state which "delivers" and can be at least relatively trusted is today needed more than ever. Self-organization of local communities will do its work only in combination with the state apparatus - and with science. We are now forced to admit that modern science, in spite of all its hidden biases, is the predominant form of transcultural universality. The epidemic provides a welcome opportunity for science to assert itself in this role.

Here, however, a new problem arises. In science also, there is no big Other, no subject on whom we can fully rely, who is unquestionably presumed to know. There are different conclusions, as well as different proposals about what to do, advocated by serious epidemiologists. Even what is presented as data is obviously filtered by horizons of preunderstanding: how to decide if an old weak person really died of the virus? Plus, although the fact that many more people are still dying from other diseases than from coronavirus should not be misused to alleviate the crisis, it is true that the strict focus of our healthcare system on coronavirus has led to the postponement of the treatment of diseases considered non-urgent (testing people for cancer, for liver diseases, etc.), so that our strict measures may cause more damage in the long term than the direct impact of the virus. (Not to mention the dire economic consequences of the lockdown. At the beginning of April, local food riots by the newly impoverished had already exploded in southern Italy, with police used to control food stores in Palermo.) Is the only choice 
really the one between the Chinese-style total control and a lax "herd immunity" approach? Hard decisions are to be made here which cannot be grounded just in scientific knowledge-it is easy to warn that state power is using the epidemics as an excuse to impose a state of permanent emergency, but what alternate decision do those who proliferate these warnings propose?

Our reaction to epidemics is not just a panic orchestrated by those in power (why would big capital risk a mega-crisis?), it is a genuine and well-grounded alarm. But the almost exclusive focus on the coronavirus in our media is not based on neutral facts, it is clearly based on an ideological choice. Maybe, one can afford here a modest conspiracy theory: what if the representatives of the existing global capitalist order are somehow aware of what critical Marxist analysts point out for some time - that the system as we know it is in deep crisis, that it cannot go on in its existing liberal-permissive form, and they are ruthlessly exploiting the epidemics to impose a new form. The most probable outcome of the epidemic is that a new barbarian capitalism will prevail: many old and weak will be sacrificed and let to die, workers will have to accept much lower standard of living, digital control of our lives will remain a permanent feature, class distinctions will become much more than now a matter of life and death. How much of the communist measures that those in power are now compelled to enforce will remain?

So, we shouldn't lose too much time in New Age spiritualist meditations on how "the virus crisis will enable us to focus on what our lives are really about," and so on. The real struggle will be: what social form will replace the liberal-capitalist new world order? This is our true appointment in Samarra.

\section{References}

Bennett, J. 2010. Vibrant matter. Durham: Duke University Press. Hanage, W. 2020. I'm an epidemiologist. When I heard about Britain's "herd immunity" coronavirus plan, I thought it was satire. The Guardian, March 15. https://www.theguardian. com/commentisfree/2020/mar/15/epidemiologist-britainherd-immunity-coronavirus-covid-19. Accessed July 29, 2020.

Kapuscinski, R. 1992. Shah of shahs. New York: Vintage Books. Latour, B. 2020. Is this a dress rehearsal? Critical Inquiry, March 26. https://critinq.wordpress.com/2020/03/26/is-thisa-dress-rehearsal/. Accessed July 29, 2020.

Müller, M. 2015. Assemblages and actor-networks: Rethinking socio-material power, politics and space. Geography Compass 9(1): 27-41.

Publisher's note Springer Nature remains neutral with regard to jurisdictional claims in published maps and institutional affiliations. 